\title{
DINAMIKA POLITIK; SOLUSI AKHIR EKSISTENSI KONFLIK DAN PENGARUHNYA TERHADAP MASYARAKAT PASCA PERDAMAIAN DI ACEH BESAR
}

\author{
Usman $^{1)}$, Cut Megawati ${ }^{2)}$ \\ ${ }^{1)}$ Program Studi Pendidikan Pancasila dan Kewarganegaraan, FKIP, Universitas \\ Abulyatama, email : usman@abulyatama.ac.id \\ ${ }^{2)}$ Fakultas Hukum Universitas Abulyatama, email : cutmegawati@gmail.com
}

\begin{abstract}
This study was aimed to investigate whether there is still an effort to maintain the final solution of conflict existence in the politic and its impact to the society after the peace agreement has been signed. This study used the descriptive qualitative approach by using interview and observation as data collection. The research findings revealed several indicators of conflict existence; they were unfairness, dishonesty, structured, massive and sistematic fraud that is still occured in politic democratic such as black campaign and money politics. As the impact, these indicators remain as a trigger of conflict that cause violence acts in the society in almost every part of Aceh which also occured in Aceh Besar. The most likely impact in the society was a demonstration which often happen in a campaign that often followed by violence acts, terror, and also intimidation.
\end{abstract}

\section{Keywords : politic, solution, conflict, society, peace, aceh}

\begin{abstract}
Abstrak: Tujuan penelitian ini untuk mengetahui masih tetap ada dan berlangsungnya solusi akhir eksistensi konflik dalam dinamika politik pasca perdamaian dan pengaruh solusi akhir eksistensi konflik dalam dinamika politik terhadap masyarakat pasca perdamaian di Aceh. Penelitian ini menggunakan pendekatan penelitian deskriptif kualitatif dengan teknik pengumpulan data wawancara dan observasi lapangan. Hasil penelitian ini adalah penyebab muncul dan berlangsungnya eksistensi konflik pasca perdamaian sering sekali disebabkan oleh indikator, sebagai berikut adanya ketidakadilan, ketidakjujuran, dan kecurangan yang terstruktur, masif, dan sistematis yang masih tetap digunakan dalam perpolitikan yang demokratis, contohnya: black campaign (kampanye hitam) dan money politics (politik uang). Sehingga indikator tersebut masih tetap menjadi pemicu munculnya keberlangsungan konflik hingga terjadinya anarkisme masyarakat dalam masa perpolitikan, dan tak jarang pula sering terjadi hampir di setiap daerah di Aceh, termasuk di Aceh Besar. Dampaknya terhadap masyarakat Aceh Besar adalah demonstrasi, kampanye yang dilakukan oleh masyarakat berujung dengan penggunaan tindakan anarkisme, teror, intimidasi dan kekerasan politik.
\end{abstract}

Kata kunci : politik, solusi, konflik, masyarakat, perdamaian, aceh

Dinamika dalam sebuah kelompok sering ditentukan oleh orang-orang yang berpengaruh di dalamnya. Dinamika juga dapat diartikan sebagai suatu proses pergerakan yang mengalami perubahan seiring dengan berjalannya waktu, gerak politik dapat terjadi di berbagai daerah Indonesia, termasuk di Aceh. Banyak hal yang dapat mempercepat proses keberlangsungannya, 
seperti eksitensi konflik yang memberikan pengaruh terhadap aspek sosial, ekonomi, budaya dan politik masyarakat. Peninjauan dinamika melalui segi ilmu politik memberikan pemahaman mengenai situasi dan kondisi perpolitikan yang terjadi.

Perpolitikan di Aceh pada umumnya dikaitkan dengan upaya penyelesaian konflik yang terjadi sebelum pasca perdamaian, dan dalam catatan sejarahnya, daerah Aceh dianggap termasuk ke dalam daerah yang tidak pernah lepas dari pada konflik, Pasca kemerdekaan Indonesia, konflik antara Aceh dan Pemerintah Pusat pertama kali terjadi pada saat gerakan Darul Islam (DI/TII) Pimpinan Teungku Daud Beureueh diproklamirkan pada tahun 1953 (Usman, 2003:124).

Wilayah Aceh merupakan wilayah yang tidak berhasil dikuasai pihak Belanda dalam Agresi Militer II yang dilancarkannya pada bulan Desember tahun 1948 sampai dengan tahun 1949, akibat dari serangan tersebut Belanda berhasil menawan Presiden Soekarno dan Wakil Presiden Mohd. Hatta (Presiden dan Wakil Presiden pertama Indonesia) serta menguasai hampir seluruh wilayah Indonesia. Kemudian dibentuknya Pemerintah Darurat Republik Indonesia (PDRI) di Bukit Tinggi, Sumatera Barat, pada 17 Desember 1949 oleh Wakil Perdana Menteri Syafruddin Prawiranegara yang kemudian menetapkan Aceh sebagai provinsi dengan mengangkat Teungku Daud Beureueh menjadi Gubernur Militer. Sebelumnya, Aceh berada satu provinsi dengan Sumatera Utara, berpusat di Medan. Ironisnya, Provinsi hanya berumur setahun. Setelah situasi aman, pemerintah menghapus status provinsi itu sekaligus mencabut jabatan dari Daud Beureueh. Sejak itu, kekecewaan demi kekecewaan mewarnai situasi Aceh. Luka lama meluap kepermukaan.Warga teringat janji-janji pemerintah soal penegakan syariat Islam. Situasi memanas setelah aparat melakukan penangkapan terhadap sejumlah tokoh yang dianggap bersuara keras. Kebanyakan yang ditangkap itu adalah ulama yang dulunya berjasa dalam perang mengusir Belanda. Pada 17 Agustus 1949, Kartosuwiryo sudah membentuk gerakan yang mendeklarasikan Negara Islam di Jawa Barat dengan nama Darul Islam/Tentara Islam Indonesia (DI/TII), kemudian pada 21 September 1953, Daud Beureueh pun memutuskan perang melawan Pemerintah Indonesia dengan menyatakan keinginannya untuk bergabung dalam gerakan Darul Islam/Tentara Islam Indonesia (DI/TII) pimpinan Kartosuwiryo. Konflik antara Aceh dengan Pemerintah Pusat pasca kemerdekaan Indonesia kemudian mereda, dengan diberikannya hak khusus oleh Pemerintah Pusat untuk Aceh berupa otomomi dalam bidang Agama, Adat, dan Pendidikan sehingga gencatan senjata berhasil dilakukan pada tahun 1957 sampai dengan 1959 (Majalah Aceh Kita, Agustus 2005:16).

Perundingan menjadi alternatif terbaik dalam mengakhiri konflik yang terjadi antar kelompok untuk mencapai perdamaian dari suatu kesepakatan yang telah disepakati bersama. Merujuk kepada perdamaian yang tercapai pada era Teungku Daud Beureueh dengan Pemerintah 
Pusat, maka Nota Kesepahaman atau MoU (Memorandum of Understanding) yang dilaksanakan pada 15 Agustus 2015 berlokasi di Helsinki, Finlandia bukanlah otomatis telah menyelesaikan konflik Aceh melainkan telah dapat menghentikan permusuhan/peperangan dan membuka jalan untuk menyelesainkan berbagai persoalan yang kontroversial selama ini (Ismail, 2008:278).

Dengan demikian eksistensi konflik masih tetap ada dengan berbagai kepentingan kekuasaan yang terdapat dalam lingkup dinamika politik yang berpengaruh terhadap masyarakat pasca perdamaian. Karena itu, perdamaian dianggap menjadi bagian dari Hak Asasi Manusia (HAM) dalam terciptanya situsi dan kondisi kondusif akibat dari peperangan yang terjadi sebelumnya melalui komunikasi politik. Implementasi tersebut, diharapkan dapat memberikan perubahan kearah yang lebih baik bagi masyarakat di Aceh.

\section{KAJIAN PUSTAKA}

Menurut Setiadi dan Kolip (2011:345) Istilah "konflik" secara etimologis berasal dari bahasa Latin "con" yang berarti bersama dan "figere" yang berarti benturan atau tabrakan. Dalam Kamus Bahasa Indonesia (Tim Penyusun, 2008:746) konflik diartikan sebagai "percekcokan, perselisihan atau pertentangan". Surbakti (1992:149) mengemukakan pandangannya terkait konflik adalah Istilah konflik dalam ilmu politik acapkali dikaitkan dengan kekerasan, seperti kerusuhan, kudeta, terorisme, dan revolusi. Konflik mengandung pengertian "benturan", seperti perbedaan pendapat, persaingan, dan pertentangan antara individu dan individu, kelompok dan kelompok, individu dan kelompok, dan antara individu atau kelompok dengan pemerintah.

Konflik dianggap sebagai suatu perjuangan dalam memperoleh hal-hal yang langka seperti nilai, status, kekuasaan, dan sebagainya, sebagaimana dikemukakan Lawang (1994:53), yaitu konflik sebagai perjuangan untuk memperoleh hal-hal yang langka seperti nilai, status, kekuasaan, dan sebagainya dimana tujuan mereka berkonflik itu tidak hanya memperoleh keuntungan tetapi juga untuk menundukkan pesaingnya. Konflik dapat diartikan sebagai benturan kekuatan dan kepentingan antara satu kelompok dengan kelompok lain dalam proses perebutan sumber-sumber kemasyarakatan (ekonomi, politik, sosial, dan budaya) yang relatif terbatas.

Konflik diidentikkan sebagai tindakan penggunaan kekerasan, sebagaimana dikemukakan Soekanto (1992:86), konflik adalah pertentangan atau pertikaian suatu proses yang dilakukan orang atau kelompok manusia guna memenuhi tujuannya dengan jalan menentang pihak lawan yang disertai ancaman dan kekerasan. Oleh karena itu, konflik di identikkan dengan tindakan kekerasan.

Proses terjadinya konflik, Khaldun (Susan, 2009:34) berpendapat bahwa bagaimana dinamika konflik dalam sejarah manusia sesungguhnya ditentukan oleh keberadaan kelompok sosial ('ashobiyah) berbasis pada 
identitas, golongan, etnis, maupun tribal. Kelompok sosial dalam struktur sosial mana pun dalam masyarakat dunia memberi kontribusi terhadap berbagai konflik.

$$
\text { Setiadi dan Kolip }
$$
mengemukakan pendapat para sosiolog terkait dengan proses terjadinya konflik, bahwa akar dari timbulnya konflik yaitu adanya hubungan sosial, ekonomi, politik, yang akarnya adalah perebutan atas sumber-sumber kepemilikan, status sosial, dan kekuasaan yang jumlah kesediaannya sangat terbatas dengan pembagian yang tidak merata di masyarakat.

Berdasarkan uaraian di atas dapat disimpulkan dalam dinamika politik yang terjadi, eksistensi konflik masih tetap ada dan berlangsung dikarena terdapatnya hubungan ekonomi, sosial dan politik sebagai status sosial dengan jumlah terbatas. Sehingga dapat menimbulkan penggunaan tindakan kekerasan, seperti peperangan yang dilakukan untuk mencapai tujuan. Damai dapat dijadikan solusi akhir untuk menghentikan genjatan senjata sehingga proses perundingan antara pihak yang bertikai dapat terjadi.

\section{METODE PENELITIAN}

Pendekatan yang digunakan dalam penelitian ini adalah pendekatan deskriptif kualitatif. Menurut Sugiyono (2010:239) “Tujuan utama penelitian yang menggunakan pendekatan kualitatif yaitu untuk mengembangkan pengertian, konsep-konsep, yang pada akhirnya menjadi teori, tahap ini dikenal sebagai grounded theory research" Penelitian ini dilakukan di kota
Janto ibu kota Kabupaten Aceh Besar. Pemilihan subjek penelitian dilakukan dengan teknik purposive random sampling. Teknik ini digunakan untuk menyesuaikan dengan tujuan penelitian, sehingga subjek yang dipilih diharapkan dapat menjadi sumber data yang komunikatif, transparan serta representatif. Adapun subjek dalam penelitian ini adalah beberapa Partai Politik (Parlok dan Parnas), Tokoh Politik, Tokoh Agama dan Tokoh Pemuda dan tokoh perempuan. Teknik pengumpulan data melalui wawancara berbasis tugas pemetaan konsep, dengan teknik analisis data adalah reduksi data, penyajian data dan penarikan kesimpulan.

\section{HASIL DAN PEMBAHASAN}

\section{Indikator Penyebab Muncul dan} Berlangsungnya Eksistensi Konflik Politik Pasca Perdamaian di Aceh Besar

Penyebab muncul dan berlangsungnya eksistensi konflik pasca perdamaian sering sekali disebabkan oleh indikator, sebagai berikut adanya ketidakadilan, ketidakjujuran, dan kecurangan yang terstruktur, masif, dan sistematis yang masih tetap digunakan dalam perpolitikan yang demokratis, contohnya: black campaign (kampanye hitam) dan money politics (politik uang). Sehingga indikator tersebut masih tetap menjadi pemicu munculnya keberlangsungan konflik hingga terjadinya anarkisme masyarakat dalam masa perpolitikan, dan tak jarang pula sering terjadi hampir di setiap daerah di Indonesia, khususnya di Aceh Besar. Sugeng (2014:246) berpendapat "Pemilihan 
umum harus diselenggarakan dengan menganut asas langsung, umum, bebas, rahasia, jujur, dan adil”. Selanjutnya, Trijono (2009:65) menjelaskan kecenderungan konflik terkini bisa diidentifikasikan dari bekerjanya tiga faktor utama, antara lain:

(1) Situasi konflik terkini (ketegangan atau tensi struktural bersumber dari akar konflik di masa lalu belum tertangani ditambah dampak konflik pada masyarakat).

(2) Pendorong konflik (perubahanperubahan berlangsung seperti kebijakan yang men-drive konflik, krisis ekonomi, de-agrarianisasi, urbanisasi, dinamika politik lokal dan nasional, dan sebagainya).

(3) Pemicu konflik (sengketa-sengketa warga terkait pemanfaatan sumberdaya dalam kehidupan sehari-hari).

Hasil assesmen ketiganya menghasilkan indeks kerentanan konflik (conflict vulnerabilities index) mengindikasikan tingkat kerawanan daerah-daerah pasca konflik. Perubahan-perubahan berlangsung di masyarakat yang mendorong potensi konflik terpendam muncul ke permukaan dan tensi-tensi sosial meningkat, perlu mendapat tekanan khusus dalam assesmen.

Tingkat kerawanan konflik yang terjadi di kawasan Aceh Besar tidak separah yang dialami kawasan-kawasan lainnya di Provinsi Aceh. Kecenderungan yang sering terjadi seperti pengrusakan spanduk atau baliho calon kandidat pertahana, tidak sampai tahapan terjadinya penembakan ataupun pembunuhan. Di kawasan Aceh Besar mulai terjadinya penurunan tingkat penggunaan kekerasan dalam dinamika politik dari tahun-tahun sebelumnya.

Huntington dan Nelson (Budiardjo, 2008:370) beranggapan bahwa "Kegiatan yang ada unsur destruktifnya, seperti demonstrasi, teror, pembunuhan politik, dan lain-lain, merupakan suatu bentuk partisispasi”.

Akan tetapi, suatu bentuk tindakan partisipasi, yang melanggar hukum, seperti teror, penembakan, bahkan pembunuhan tetap akan dikenai sanksi yang berlaku sesuai dengan pasal yang terdapat pada Kitab Undang-Undang Hukum Pidana (KUHP). Sehingga tujuan dari suatu hukum yang ideal, sebagaimana dikemukakan Rodee,dkk (2014:81-82) "Haruslah mencapai keadilan. Itu sama artinya bahwa antara sesama umat manusia dan antara mereka dengan negara ada hubungan yang harmonis".

\section{Pengaruh Eksistensi Konflik} Perpolitikan Terhadap Masyarakat di Aceh Besar

Pengaruh eksistensi konflik perpolitikan terhadap masyarakat di Aceh Besar akibat dari penggunaan indikator ketidakadilan, ketidakjujuran, dan kecurangan yang terstruktur, masif, dan sistematis, yaitu: dapat menghilangkan kepercayaan masyarakat terhadap kepemimpinan yang tidak amanat. Nilai-nilai demokratis masyarakat dalam perpolitikan tercemari dengan hal-hal yang tidak sepatutnya ditiru. Strategi dari penerapan 
demokrasi terhadap masyarakat tidak hanya menjadi suatu sistem di pemerintahan semata, melainkan juga dapat menjadi suatu gaya hidup serta tatanan masyarakat yang memiliki unsusrunsur nilai moral, sebagai dikemukakan Henry

B. Mayo (Budiarjo, 2008:118) di bawah ini:

1) Menyelesaikan perselisihan dengan damai dan secara melembaga (Institusionalized peaceful settlement of conflict).

2) Menjamin terselenggaranya perubahan secara damai dalam suatu masyarakat yang sedang berubah (Peaceful change in a changing society).

3) Menyelenggarakan pergantian pimpinan secara teratur (Ordely succession of rulers).

4) Membatasi pemakaian kekerasan sampai minimum (Minimum of coercion).

5) Mengakui serta menganggap wajar adanya keanekaragaman (diversity) dalam masyarakat yang tercermin dalam keanekaragaman pendapat, kepentingan serta tingkah laku.

6) Menjamin tegaknya keadilan.

Huntington (Djaffar, 2008:196) mengemukakan pencapai demokrasi melalui berbagai penggunaan strategi yaitu pencapaian demokrasi dapat dicapai melalui pelbagai strategi, misalnya, perundingan, kompromi, dan perjanjian dengan menempuh prosedur yang demokratis, seperti demonstrasi, kampanye, dan pemilihan umum, serta penyelesaian perbedaan tanpa kekerasan.
Pengaruhnya yang timbul dari mengabaikan pelbagai strategi pencapaian demokrasi dapat memicu demonstrasi dengan penggunaan tindakan anarkisme masyarakat dikemudian harinya. Masyarakat bahkan ada yang memilih untuk menjadi golongan putih (golput) dalam memberikan suaranya pada pemilu perpolitikan Aceh Besar. Ada beberapa jawaban perihal apatisme yang muncul pada masyarakat, sebagaimana dikemukakan Budiardjo (2008:370), adalah mereka tidak ikut pemilihan karena sikap acuh tak acuh dan tidak tertarik pada, atau kurang paham mengenai masalah politik. Ada juga karena tidak yakin bahwa usaha untuk mempengaruhi kebijakan pemerintah akan berhasil, dan ada juga yang sengaja tidak memanfaatkan kesempatan memilih karena kebetulan berada di lingkungan di mana ketidaksertaan merupakan hal yang dianggap biasa.

Apatisme yang terjadi pada masyarakat menunjukkan adanya pengaruh daripada dampak konflik di masa lalu. Trijono (2009:64-65) berpendapat "Assesmen" terhadap dampak konflik di masa lalu dilakukan untuk mengetahui situasi konflik terkini, mengidentifikasi kecenderungan kembali terjadinya konflik (conflict trend/relapsed) yang bisa membuyarkan upaya perdamaian".

\section{KESIMPULAN DAN SARAN}

Kesimpulan yang ditemukan dari penelitian yang telah dilakukan sebagai berikut:

1. Pra perdamaian di Aceh, tindakan penggunaan kekuasaan paksaan oleh 
Pemerintahan Pusat secara berlebihan, seperti penggunaan kekerasan terhadap masyarakat dalam penyelesaian konflik di Aceh memberikan kesulitan, sehingga penggunaan tindakan kekuasaan konsensus yang telah ditransformasi dapat memberikan kemudahan dalam penyelesaian konflik terhadap masyarakat Aceh, akan tetapi memerlukan proses waktu yang lama sehingga perdamaian tersebut terjadi. Pasca perdamaian, masih tetap ada dan berlangsungnya eksistensi konflik dalam perpolitikan disebabkan karena adanya ketidakadilan, ketidakjujuran, dan kecurangan yang terstruktur, masif, dan sistematis yang masih tetap digunakan dalam perpolitikan yang demokratis. Dampaknya terhadap masyarakat di Aceh Besar yaitu demonstrasi, kampanye yang dilakukan oleh masyarakat dapat berujung dengan penggunaan tindakan anarkisme. Akan tetapi, tingkat kerawanan yang terjadi di kawasan Aceh Besar tidak separah kawasan-kawasan lainnya di Provinsi Aceh.

2. Kolaborasi konsep keadilan yang dipadupadankan dengan konsep adat budaya lokal masyarakat dalam penyelesaian eksistensi konflik setidaknya memberikan solusi bagi masyarakat di Aceh Besar, sehingga tatanan sistem hukum dan norma yang berlaku dapat diterapkan sesuai dengan aturannya. Mahkamah Konstitusi dapat menggunakan wewenangannya dalam menciptakan keadilan bagi masyarakat yang berseteru dalam perpolitikan pilkada sesuai dengan prosedural hukum yang berlaku. Masyarakat di Aceh Besar dapat menggunakan sistem adat budaya lokal terlebih dahulu sebagai bentuk pencegahan dalam penyelesaian permasalahan sebelum ditindaklanjuti ke sistem hukum negara.

\section{DAFTAR PUSTAKA}

Budiardjo, Miriam. (2008). Dasar-Dasar Ilmu Politik. Jakarta: PT Gramedia Pustaka Utama.

Conflict Resolution Training. Lembar Kasus 6.1. Konflik dan Pembangunan di Aceh:Profil Sosio-grafis

NAD.hlm 97. Diakses 9 Februari 2016 dari https://wahyudimukti.files.wordpress.c om/2010/09/konflik-danpembangunan-di-aceh.pdf.

Damsar. (2012). Pengantar Sosiologi Politik. Jakarta: Kencana.

Djaffar, TB. Massa. (2008). Pilkada dan Demokrasi Konsosiasional di Aceh. Jurnal Kajian Politik dan Masalah Pembangunan, 4(1).

Gaffar,Afan. (2004). Budaya Politik Indonesia. Yogyakarta: Pustaka Pelajar.

Gayo, Iwan. (2007). BukuPintar Seri Senior. Jakarta Selatan: Pustaka Warga Negara.

Hardiman, F. Budi et al. (2011). Empat Esai Etika Politik. Jakarta Pusat: dari www.srimulyani.net.

Ismail, Badruzzaman. (2008). Sistem Budaya Adat dalam Membangun 
Kesejahteraan (Nilai Sejarah dan Dinamika Kekinian). Banda Aceh: Majelis Adat Aceh (MAA) Provinsi Nanggroe Aceh Darussalam.

Lawang, Robert. (1994). Buku Materi Pokok Pengantar Sosiologi. Jakarta: Universitas Terbuka.

Latief, Yuni Roslaili Usman. (2016). Serambi Opini: Pemimpin yang Melayani. Banda Aceh: PT. Aceh Media Grafika.

Melalatoa, M. Junus, dkk. (2005). Aceh Kembali ke Masa Depan. IKJ Press bekerjasama dengan KataKita. Yayasan SET, PT Gudang Garam.

Nasir, Muhammad. (2017). Di Aceh Besar Mawardi Ali Menang di 18 Kecamatan. diakses 18 Februari 2017 dari https://aceh.tribunnews.com/2017/02/1 6/di-aceh-besar-mawardi-ali-menangdi-18-kecamatan.

Noer, Deliar. (1965). Pengantar ke Pemikiran Politik. Medan: Dwipa.

Rodee, Carlton Clymer, dkk. (2014). Pengantar Ilmu Politik. Jakarta: Rajawali Press.

Sarwono, Jonathan. (2006). Metode Penelitian Kuantitatif dan Kualitatif. Yogyakarta: Graha Ilmu.

Setiadi, Elly M dan Kolip, Usman. (2011). Pengantar Sosiologi Pemahaman Fakta dan Gejala Permasalahan Sosial: Teori, Aplikasi, dan Pemecahannya. Jakarta: Kencana Prenada Media Group.
Soekanto, Soerjono. (1992). Sosiologi Suatu Pengantar. Jakarta: Rajawali Pers.

Sugeng HR. (2014). Rangkuman Pengetahuan Umum Lengkap (RPUL). Semarang: Aneka Ilmu.

Sugiyono. (2010). Metode Penelitian Kuantitatif, Kualitatif dan $R D$. Bandung: Alphabeta

Surbakti, Ramlan. (1992). Memahami Imu Politik. Jakarta: PT. Gramedia Widiasarana Indonesia.

Susan, Novri. (2009). Pengantar Sosiologi Konflik dan Isu-Isu Kontemporer. Jakarta: Kencana.

Trijono, Lambang. (2009). Pembangunan Perdamaian Pasca-Konflik di Indonesia: Kaitan perdamaian, pembangunan, dan demokrasi dalam pengembangan kelembagaan pascakonflik. Jurnal Ilmu Sosial dan Ilmu Politik, 13(1), 48-70.

Usman, A. Rani. (2003). Sejarah Peradaban Aceh. Jakarta: Yayasan Obor Indonesia.

Warsidi, Adi. (2008). Bupati Aceh Besar Mengundutkan Diri. Diakses 24 Januari 2017, dari https://m.tempo.co/read/news/2008/ 09/05/bupati-aceh-besarmengundurkan-diri

Zainal, Suadi. (2016). Transformasi Konflik Aceh dan Relasi Sosial-Politik di Era Desentralisasi. Jurnal Sosiologi 21 (1), 81-108. 